\title{
Reformulasi Eksekusi Kebiri Kimia Guna Menjamin Kepastian Hukum Bagi Tenaga Medis/Dokter Dan Perlindungan Hukum Bagi Pelaku Pedophilia
}

\author{
Ari Purwita Kartika, M. Lutfi Rizal Farid, dan Ihza Rashi Nandira Putri \\ Fakultas Hukum Universitas Negeri Surabaya \\ Jln. Rektorat Unesa, Lidah Wetan, Kec. Lakarsantri, Kota Surabaya \\ aripurwitak@gmail.com; lutrizal@gmail.com; ihza547@gmail.com
}

\author{
Received: 24 Februari 2020; Accepted: 19 Juni 2020; Published: 25 Agustus 2020 \\ DOI: 10.20885/iustum.vol27.iss2.art7
}

\begin{abstract}
This research focuses on establishing chemical castration as additional criminal penalty. Chemical castration is intended to minimize sexual crimes against children. However, this additional punishment of chemical castration is conflicted with the ethics of the medical profession and the additional punishment of chemical castration is due to the lack of technical instructions for chemical castration. This is a type of normative legal research. This study concludes that: first, the regulation on the executor of the perpetrator of sexual crimes against children does not have legal certainty. A person who takes action on chemical castration is not only a person who does it, but a person who has knowledge in the field of chemical castration. This science is related to medical science which should be able to perform chemical castration. The act of chemical castration that should be done by a doctor conflicts with the professional code of ethics of a doctor. Second, the legislators must reconstruct the rules related to the implementation of chemical sanctions castration so that they are clearly regulated and do not conflict with other regulations.
\end{abstract}

Key Words: Chemical castration; professional ethichs; children

Abstrak

Penelitian ini fokus pada ditetapkannya Kebiri kimia sebagai hukuman pidana tambahan. Kebiri kimia dimaksudkan untuk meminimalisir kejahatan seksual terhadap anak. Namun, pidana tambahan kebiri kimia ini adanya pertentangan dengan etika profesi kedokteran dan pelaksanaan pidana tambahan kebiri kimia dikarenakan tidak adanya petunjuk teknis kebiri kimia. Penelitian ini merupakan jenis penelitian hukum normatif. Penelitian ini menyimpulkan bahwa: pertama, pengaturan tentang eksekutor terhadap pelaku tindak pidana seksual pada anak belum mempunyai kepastian hukum. Seorang yang melakukan tindakan terhadap kebiri kimia tersebut bukan orang yang hanya sekadar melakukannya saja, namun orang yang mempunyai ilmu dalam bidang tentang kebiri kimia. IImu tersebut berkaitan dengan ilmu kedokteran yang seharusnya dapat melakukan tindakan kebiri kimia. Tindakan kebiri kimia yang seharusnya dilakukan oleh seorang dokter berbenturan dengan kode etik profesi dokter. Kedua, pembentuk peraturan perundang-undangan harus merekonstruksi aturan terkait pelaksanaan kebiri sanksi kimia agar diatur secara jelas sehingga tidak berbenturan dengan aturan yang lain.

Kata-kata Kunci: Kebiri kimia; etika profesi; anak 


\section{Pendahuluan}

Pemberian perlindungan anak di Indonesia telah diatur dalam konstitusi, hal ini didasarkan pada Pasal 28B ayat (2) UUD NRI 1945 dinyatakan bahwa "setiap anak berhak atas kelangsungan hidup, tumbuh, berkembang, serta berhak atas perlindungan dari kekerasan dan diskriminasi." Pengertian korban seperti yang tercantum dalam Pasal 1 angka 2 Undang-Undang Republik Indonesia Nomor 13 Tahun 2006 tentang Perlindungan Saksi dan Korban menyatakan bahwa "korban adalah seseorang yang mengalami penderitaan fisik, mental, atau kerugian ekonomi yang diakibatkan oleh suatu tindak pidana." Anak sebagai korban tindak pidana kesusilaan tentunya mengalami penderitaan, baik secara fisik maupun psikis. ${ }^{1}$ Negara sebagai penjamin kehidupan bermasyarakat bermaksud memberikan perlindungan secara khusus kepada anak agar terhindar dari upaya eksploitasi oleh pihak-pihak tertentu. ${ }^{2}$

\section{Gambar 1. Usia Korban dan Pelaku Pencabulan. ${ }^{3}$}

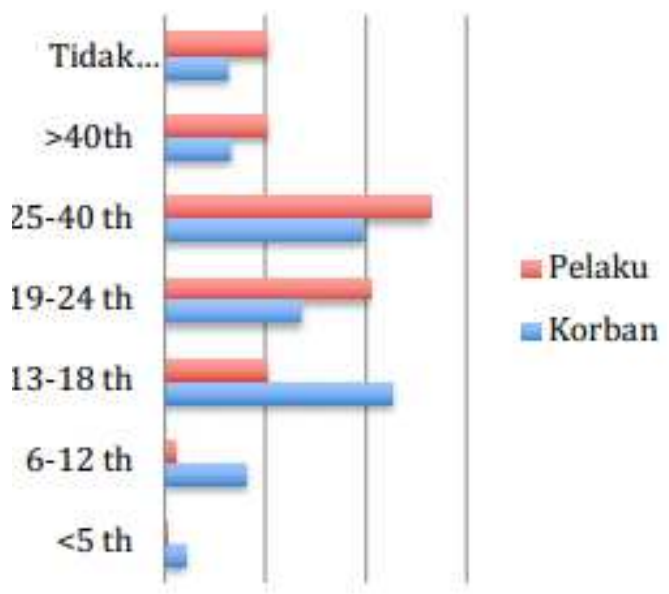

Sumber: Catatan Tahunan 2018 Komnas Perempuan, diolah penulis.

Berdasarkan Gambar 1 menunjukan bahwa yang menjadi korban dari tindak pencabulan adalah korban yang berumur 13-18 tahun. Korban yang berumur 13-18 tahun masih dianggap sebagai anak, hal tersebut sesuai dengan batas usia dalam Undang-Undang Republik Indonesia Nomor 35 Tahun 2014 tentang Perubahan Atas Undang-Undang Nomor 23 Tahun 2002 tentang

1 Akbar Sayudi, "Upaya Perlindungan Korban Tindak Pidana Perkosaan dalam Sistem Peradilan Pidana Indonesia”, Jurnal Fiat Justisia, Vol. 10, No. 2, April 2016, hlm. 211.

2 Sukirman dan Susyalina Pratiwi, "Penyuluhan tentang Hukum Perlindungan Anak", Jurnal Inovasi dan Kewirausahaan, Vol. 3, No. 2, Mei 2014, hlm. 102.

${ }^{3}$ Komnas Perempuan, Korban Bersuara, Data Berbicara, Sahkan RUU Penghapusan Kekerasan Seksual Sebagai Wujud Komitmen Negara, Hasil Penelitian, Komisi Perempuan, Jakarta, 2019, hlm. 19. 
Perlindungan Anak bahwa anak adalah seseorang yang belum berusia 18 tahun, termasuk anak yang masih dalam kandungan. ${ }^{4}$ Anak sebagai korban tindak pidana kesusilaan tentunya mengalami penderitaan, baik secara fisik maupun psikis. ${ }^{5}$ Oleh karena itu, negara sebagai penjamin kehidupan bermasyarakat bermaksud memberikan perlindungan secara khusus kepada anak agar terhindar dari upaya eksploitasi oleh pihak-pihak tertentu dengan mengeluarkan sanksi pidana dalam bentuk kebiri kimia. ${ }^{6}$

Tabel 1. Jumlah Kasus Kekerasan Seksual Pada Anak ${ }^{7}$

\begin{tabular}{cc}
\hline Tahun & $\begin{array}{c}\text { Jumlah Permohonan Terhadap Kasus } \\
\text { Kekerasan Seksual Pada Anak }\end{array}$ \\
\hline 2016 & 60 korban \\
2017 & 151 korban \\
2018 & 354 korban \\
\hline
\end{tabular}

Berdasarkan Tabel 1, menunjukkan bahwa kekerasan seksual pada anak menunjukkan peningkatan yang signifikan. Sehingga perlindungan anak seharusnya menjadi salah satu prioritas pemerintah. Kekerasan seksual terhadap anak tidak hanya korban yang menderita tetapi juga berdampak bagi sosial. ${ }^{8} \mathrm{Hal}$ tersebut dapat mengakibatkan kecacatan fisik dan ketergatungan kepada orang lain. Selain itu juga menjadi trauma psikologis, secara fisik akan tumbuh menjadi orang dewasa tetapi tidak dapat berperan secara optimal sebagai orang dewasa yang memiliki kematangan emosi dan pikir. ${ }^{9}$ Pencabulan dapat mengakibatkan korban akan kecacatan fisik dan ketergatungan kepada orang lain. Selain menjadi

4 Elvi Zahara, "Perlindungan Hukum terhadap Anak yang Melakukan Perkawinan Anak di Bawah Umur”, Mercatoria, Vol. 1, No. 2, Desember 2008, hlm. 163.

5 Sufyan Ilyas, "Sanksi Kebiri Kimiawi bagi Pelaku Pedofilia dalam Perspektif Hukum di Indonesia", AlMursalah, Vol. 1, No. 2, Juli 2015, hlm. 26.

${ }^{6}$ Ivo Noviana, "Kekerasan Seksual Terhadap Anak: Dampak dan Penanganannya", Sosio Informa, Vol. 1, 2015, hlm. 14.

7 Sumber data diolah peneliti, lihat Matius Alfons, "LPSK Kasus Kekerasan Seksual pada Anak Meningkat tiap Tahun", https://news.detik.com/berita/d-4637744/lpsk-kasus-kekerasan-seksual-pada-anakmeningkat-tiap-tahun, diakses pada 22 April 2020.

${ }^{8}$ Lihat Penny Naluria Utami, "Pencegahan Kekerasan terhadap Anak dalam Perspektif Hak Atas Rasa Aman di Nusa Tenggara Barat", Jurnal HAM, Vol.9, No. 1, Juli 2018, hlm. 5

9 Atikah Rahmi, "Urgensi Perlindungan bagi Korban Kekerasan Seksual dalam Sistem Peradilan Pidana Terpadu Berkeadilan Gender”, Mercatoria, Vol. 11, No. 1, Juni 2018, hlm. 42-50. 
trauma psikologis yaitu post traumatic setress disorder, ${ }^{10}$ korban akan mengalami angry outburst dan bunuh diri. ${ }^{11}$

Berkaitan dengan kekerasan seksual di Indonesia mengalami peningkatan tiap tahunnya, Nuzul Qur'aini Mardiya menjelaskan, bahwa hukuman pidana bagi pelaku kekerasan seksual dalam KUHP dan Undang Undang Perlindungan Anak dianggap belum efektif sehingga Pemerintah mengesahkan PERPU No.1/2016 menjadi UU 17/2016 yang menerapkan pemberatan hukuman bagi pelaku kejahatan kekerasan seksual diantaranya dengan memberlakukan kebiri secara kimia. Penerapan kebiri secara kimiawi ini menimbulkan pro kontra di masyarakat terkait efektifitasnya dan pemberlakuannya yang dianggap melanggar hak asasi manusia sebagaimana termuat dalam UUD 1945, Konvensi Internasional ICCPR dan CAT yang telah diratifikasi oleh Indonesia dan UU Nomor 39 Tahun 1999 tentang HAM. ${ }^{12}$

Berkaitan dengan hukuman tambahan kebiri kimia, Atet Sumanto menunjukkan, bahwa pelaku yang melakukan persetubuhan dengan anak (pedofilia) secara khusus telah diatur dalam Pasal 81 dan 82 PERPPU No. 1 Tahun 2016 sebagaimana telah disahkan menjadi Undang-Undang No. 17 Tahun 2016, di mana pelaku yang melakukan persetubuhan dengan anak (pedofilia) dapat di pidana penjara baik secara umum, maupun pidana penjara sebagai bentuk kualifisier seperti pidana mati, pidana seumur hidup, pidana paling singkat 10 tahun dan paling lama 20 tahun serta pidana penjara tambahan sepertiga. Selain pidana penjara, beberapa tindakan dan pidana tambahan lainnya telah diakomodasi dalam PERPPU No. 1 Tahun 2016 sebagaimana telah disahkan menjadi Undang-Undang No. 17 Tahun 2016 tersebut seperti dapat dikenakan pidana tambahan dan/atau tindakan seperti yang salah satunya adalah kebiri kimiawi untuk menghilangkan sementara nafsu seksual. Sehingga dengan adanya penerapan tindakan kebiri kimiawi ini akan memberikan jaminan kepastian

10 Ratih Probosiwi, Daud Bahransyaf, "Pedofilia dan Kekerasan Seksual: Masalah dan Perlindungan Terhadap Anak", Sosio Informa, Vol. 1, 2015, hlm. 32

11 Etty Indriati, "Child Sexuual Abuse (Pencabulan Terhadap Anak): Tinjauan Klinis dan Psikologis", Berkala Ilmu Kedokteran, Vol. 33, 2001, hlm. 117

12 Nuzul Qur'aini Mardiya, "Penerapan Hukum Kebiri Kimia Bagi Pelaku Kekerasan Seksual Implementation of Chemical Castration Punishment For Sexual Offender," Jurnal Konstitusi, Vol. 14, 2017, hlm. 214. 
hukum dalam proses penegakan hukum, jaminan keadilan bagi anak-anak dan keluarga yang menjadi korban kejahatan seksual, dan kemanfaatan bagi pelaku yang melakukan persetubuhan dengan anak (pedofilia) sebagai terapi dan pengobatan dalam mengatasi gangguan seksual. Hal itu juga terbukti efektif di Negara Bagian California, Amerika Serikat yang memberlakukan Kebiri Kimia dalam penegakan hukum terhadap pelaku yang melakukan persetubuhan dengan anak (pedofilia). ${ }^{13}$

Indonesia sebagai negara hukum turut memberlakukan Kebiri Kimia sebagai hukuman terhadap pelaku pedofilia, hal ini terbukti berdasarkan putusan Pengadilan Negeri Mojokerto menghukum M. Aris, pelaku pemerkosaan sembilan anak di sana. Pengadilan tingkat pertama dan kedua menghukum Aris dengan 12 tahun penjara, denda Rp. 100.000.000,00 dan hukuman pemberatan kebiri kimia. ${ }^{14}$ Hingga akhir Agustus 2019, Kejaksaan Negeri Kabupaten Mojokerto sedang mencari rumah sakit yang bersedia mengebiri Aris, 2 RSUD yang ada di Kabupaten Mojokerto belum ada yang bersedia dengan alasan Ikatan Dokter Indonesia (IDI) tidak bersedia mengeksekusi hukuman kebiri kimia kepada pelaku kekerasan seksual karena melanggar sumpah dan etika kedokteran. ${ }^{15}$

Dalam Kode Etik Kedokteran (KODEKI) 2012 Pasal 5 dikatakan bahwa "setiap perbuatan/nasihat dokter yang mungkin melemahkan daya tahan psikis maupun fisik, wajib memperoleh persetujuan pasien/keluarganya dan hanya diberikan untuk kepentingan dan kebaikan pasien tersebut." Pada penjelasan pasal diterangkan bahwa melemahkan psikis maupun fisik pasien bertentangan dengan fitrah ilmu kedokteran kecuali bila terdapat alasan pembenar dari tindakan tersebut, seperti prosedur penghilangan fungsi saraf yang digunakan dalam pembiusan prabedah dan pemberian obat anti nyeri pada pasien dengan nyeri tak tertahankan. Sehubungan dengan tugas, fungsi dan wewenang tenaga medis atau kesehatan (dokter) yang adalah penyembuhan dan penghormatan

\footnotetext{
13 Atet Sumanto, "Tindakan Kebiri Kimia Bagi Pelaku Tindak Pidana Persetubuhan Dengan Menggunakan Kekerasan Terhadap Anak Di Indonesia," Perspektif, Vol. 22, 2017, hlm. 140.

14 Putusan Pengadilan Negeri Mojokerto Nomor 69/Pid.Sus/2019/PN. Mjk tentang Pidana Pemerkosaan Anak, 25 Agustus 2018.

15 Fathor Rasi, Ikatan Dokter Tolak Hukuman Kebiri Kimia, https://www.jatimpos.id/kabar/ikatandokter-tolak-hukuman-kebiri-kimia-b1Xlj9bUr, diakses pada 20 April 2020.
} 
hidup manusia secara alami, maka organisasi profesi telah mengeluarkan fatwa MKEK PB IDI No. 1 Tahun 2016 yang pada prinsipnya bahwa "tugas yang bertentangan dengan penyembuhan adalah bukan tugas profesi dokter". ${ }^{16}$ Dapat disimpulkan bahwa selain dari tindakan yang bertujuan menyembuhkan pasien, menghilangkan fungsi tubuh normal pasien bertentangan dengan tugas seorang dokter. Hal ini kemudian berlaku pada prosedur hukuman kebiri.

Hal ini terlihat dari penyataan Ketua Umum IDI, Ilham Oetama Marsis, bahwa ia meminta pemerintah tidak melibatkan dokter sebagai eksekutor dalam pelaksanaan hukuman kebiri. Ilham berargumen bahwa pengebirian itu akan bertentangan dengan fatwa Majelis Kehormatan dan Kode Etik Kedokteran (MKEK) Nomor 1 Tahun 2016 tentang Kebiri Kimia, Sumpah Dokter, Serta Kode Etik Kedokteran. Selain itu, Ketua MKEK, Prijo Sidipratomo mengatakan bahwa dokter yang akan megeksekusi kebiri kimia akan dikeluarkan dari profesi dokter. Apabila suntikan obat kebiri kimia tidak diberikan oleh ahlinya, maka tentunya bisa berbahaya bagi kesehatan bahkan nyawa dari pelaku kekerasan seksual terhadap anak.

Kode Etik Kedokteran telah mengatur bahwa seorang dokter harus menjadi pelindung kehidupan. Berdasarkan Pasal 11 Kode Etik Kedokteran yang menyatakan bahwa "Setiap dokter wajib senantiasa mengingat kewajiban dirinya melindungi hidup makhluk insani". Hal lain yang akan menjadi ganjalan, seorang dokter bertindak harus dengan inform consent atau persetujuan tindakan medis dari pasien atau keluarganya. Tanpa itu, dokter tidak bisa melakukan tindakan medis. Penolakan Ikatan Dokter Indonesia (IDI) dan Majelis Kehormatan dan Kode Etik Kedokteran (MKEK) menjadi eksekutor hukuman kebiri yang bertolak belakang dengan keinginan pemerintah membuat timbulnya kebingunan dan tanda tanya dari masyarakat.

\section{Rumusan Masalah}

Berdasarkan uraian sebelumnya, maka menarik untuk dikaji lebih lanjut. Sehingga artikel ini akan mengkaji mengenai, pertama, bagaimana kode etika profesi kedokteran meninjau kewenangan dokter sebagai eksekutor kebiri kimia?

\footnotetext{
16 Soetedjo, Julitasari Sundoro, Ali Sulaiman, "Tinjauan Etika Kedokteran Indonesia", Jurnal Etika Kedokteran Indonesia, Vol. 2, 2018, hlm. 70.
} 
dan kedua, bagaimana ius constituendum mengatur hak asasi manusia pelaku pedofilia dan kepastian hukum dokter selaku eksekutor kebiri kimia?

\section{Tujuan Penelitian}

Berdasarkan rumusan masalah tersebut, maka tujuan penelitian yang ingin dicapai adalah, sebagai berikut, Pertama, memahami kode etika profesi dalam memberikan kewenangan terhadap dokter sebagai eksekutor kebiri kimia. Kedua, memahami bagaimana hukum yang akan datang dapat menjamin kepastian hukum dokter selaku eksekutor kebiri kimia dan menjamin hak asasi manusia pelaku pedofilia.

\section{Metode Penelitian}

Artikel ini berdasarkan penelitian hukum normatif atau doktrinal. Dalam penelitian ini menggunakan bahan hukum primer adalah Undang-Undang Nomor 35 Tahun 2014 tentang Perubahan Atas Undang-Undang Nomor 23 Tahun 2002 tentang Perlindungan Anak dan Kitab Undang-Undang Hukum Pidana. Sedangkan bahan hukum sekunder berupa hasil penelitian, jurnal ilmiah, bukubuku teks, dan berita online yang berkaitan dengan hukuman tambahan kebiri kimia. Sifat analisis dari penelitian ini adalah preskriptif yang mana memberikan argumentasi untuk memberikan penilaian mengenai pembentukan atau tidak dibentuk peraturan pelaksana atau petunjuk teknis dari hukuman tambahan kebiri kimia. Pendekatan penelitian ini menggunakan pendekatan perundangundangan (statute approach), pendekatan konseptual (conseptual approach), dan pendekatan perbandingan (comparative approach).

\section{Hasil Penelitian dan Pembahasan}

\section{Kode Etika Profesi dalam Memberikan Kewenangan Terhadap Dokter Sebagai} Eksekutor Kebiri Kimia

Advokat, Guru, Dokter, Akuntan dan lain sebagainya merupakan beberapa jenis profesi di Indonesia yang memiliki Kode Etik Profesi. ${ }^{17}$ Kaitannya dengan permasalahan kebiri kimia, terdapat pertentangan antara beberapa etik yang

${ }_{17}$ Mispiyanti, "Peranan Etika Profesi dalam Perilaku Akuntan", Jurnal Fokus Bisnis, Vol. 15, No. 1, Juli 2016, hlm. 33. 
tercantum dalam Kode Etik Kedokteran dengan kenyataan bahwa dokter sebagai profesi yang ditunjuk oleh pengadilan untuk menjadi eksekutor kebiri kimia. Dokter sebagai profesi yang memiliki kompetensi di bidang kesehatan dengan diterapkannya hukuman kebiri kimia di Indonesia kemudian menghadapi dilema terkait tinjauan etik kedokteran yang ada terhadap fenomena ini. Ikatan Dokter Indonesia (IDI) telah mengeluarkan fatwa penolakan dokter sebagai eksekutor kebiri yang dinilai dapat mencederai sumpah profesi, mengingat efektivitas kebiri yang masih dipertanyakan dan risiko komplikasi lain yang harus dihadapi terpidana dengan hukuman kebiri.

Ketua Umum IDI Daeng M. Faqih mengatakan bahwa IDI mempersilahkan apabila Indonesia menerapkan hukuman berupa kebiri kimia. Tetapi IDI meminta agar jangan menunjuk tenaga medis atau tenaga Kesehatan sebagai eksekutor. Alasan IDI menolak sebagai eksekutor hukuman kebiri kimia ialah pertama, bahwa kebiri kimia bukan termasuk jenis pelayanan medis melainkan hukuman, jadi bukan ranah tenaga medis maupun kesehatan untuk melakukannya. Oleh karenanya, IDI mempersilahkan pemerintah menunjuk eksekutor di luar tenaga medis. Alasan kedua IDI menolak sebagai eksekutor adalah bahwa tindakan eksekusi tersebut dapat menimbulkan konflik norma yaitu etika kedokteran, perintah organisasi Kesehatan dunia (WHO), dan undang-undang Kesehatan yang melarang melakukan tindakan tersebut yang dalam hal ini adalah ekseskusi kebiri kimia. ${ }^{18}$

Kebiri atau kastrasi merupakan tindakan bedah dan/atau penggunaan bahan kimia dengan tujuan untuk menghilangkan fungsi organ reproduksi berupa testis pada jantan maupun ovarium pada betina. Berdasarkan pengertiannya, prosedur kebiri kemudian dikelompokkan menjadi kebiri fisik dan kebiri kimia. Pada kebiri fisik, operator melakukan pengangkatan total pada organ reproduksi, yakni testis maupun ovarium. Pada kebiri kimia, tindakan seperti itu tidak dilakukan, melainkan diganti dengan pemberian senyawa kimia yang mampu memperlemah atau menghilangkan fungsi dari hormon seks. Secara patofisiologi, kebiri kimia dilakukan dengan menyuntikkan hormon anti-

18 M. Naufal Hafizh, “Alasan IDI Tolak Jadi Eksekutor Kebiri Kimia Tersangka Kejahatan Sesual”, https://www.ayobandung.com/read/2019/08/27/61771/alasan-idi-tolak-jadi-eksekutor-kebiri-kimia-tersangkakejahatan-seksual, diakses tanggal 20 April 2020. 
testosteron ke dalam tubuh terpidana. Hormon tersebut bekerja dengan cara menekan produksi dan aktivitas testosteron sehingga tidak memunculkan pacuan libido selama orang tersebut berada dalam pengaruh obat tersebut.

Dewasa ini, tindakan kebiri dilakukan dengan tujuan sebagai sanksi pidana terhadap pelaku kejahatan seksual seperti pemerkosa dan pedofil di berbagai negara. Setiap negara menerapkan metode kebiri yang beragam. Republik Ceko dan Jerman adalah contoh beberapa negara yang menerapkan hukuman kebiri fisik yakni dengan pengangkatan testis para pelaku kejahatan pedofil sebagai upaya kendali dari dorongan seksual abnormal yang dimiliki pelaku. Adapun negara yang menerapkan hukuman kebiri kimia yakni Rusia dan Korea Selatan bagi para pelaku kejahatan seksual yang berisiko mengulang kejahatannya setelah dilakukan konsultasi dengan psikiater. ${ }^{19}$

Berdasarkan prinsip etika kedokteran yang terkandung dalam Sumpah Hipokrates, menyebabkan kematian atau kecacatan pada seseorang bertentangan dengan prinsip nonmaleficence atau "do no harm". Kemudian, pidana juga tidak berada dalam situasi yang memperbolehkannya untuk memberikan informed consent atau persetujuan, yang mana merupakan bagian dari prinsip autonomi dalam Sumpah Hipokrates. ${ }^{20}$ Butir ke lima pada sumpah hipokrates yang berbunyi "Saya tidak akan menggunakan pengetahuan dokter saya untuk sesuatu yang bertentangan dengan perikemanusiaan sekalipun diancam" menambah dasar alasan penguat bagi dokter untuk tidak menggunakan keahliannya yang dampaknya adalah bertentangan dengan perikemanusiaan. Tak hanya menyalahi sumpah hipokrates, eksekusi hukuman kebiri kimia yang apabila dilakukan oleh dokter juga akan menyalahi Kode Etik Kedokteran 2012 Pasal 5 yang menyatakan bahwa "Tiap perbuatan atau nasihat yang mungkin melemahkan daya tahan psikis maupun psikis, wajib memperoleh persetujuan pasien atau keluarganya dan hanya diberikan untuk kepentingan dan kebaikan pasien tersebut."

Dua hal tersebut, butir ke lima sumpah hipokrates dan Pasal 5 Kode Etik Kedoteran 2012 merupakan bentuk uraian yang jelas dari asas yang terdapat pada

${ }^{19}$ Soetedjo, Julitasari Sundoro, Ali Sulaiman, ..., Op. Cit., hlm. 68.

20 Soetedjo, Julitasari Soendoro, Pukovisa Prawiroharjo, "Tinjauan Etika: Dokter sebagai Eksekutor Hukum Pidana yang Menyebabkan Kematian, Kecacatan, atau Gangguan Kesehatan”, Jurnal Etika Kedokteran Indonesia, Vol. 1, 2017, hlm. 21. 
profesi kedokteran yakni, asas "do no harm" dan asas "informed consent." Kedua pilar asas kedokteran tersebut yang akan tersimpangi apabila dokter melakukan eksekusi hukuman kebiri kimia. Kebiri kimia mengingat efek sampingnya berupa penurunan kadar hormon testosterone yang akan berdampak pada gangguan fungsi organ tubuh lainnya, seperti atrofi otot, pengeroposan tulang, berkurangnya sel darah, dan gangguan pada fungsi kognitif tentu saja akan sangat membahayakan bagi orang yang terdampak sehingga asas "do no harm" telah dikesampingkan.

Dokter tidak perlu untuk meminta persetujuan dari orang yang akan di eksekusi karena kebiri kimia merupakan hukuman yang telah jelas apabila telah diputuskan oleh pengadilan terhadap seseorang tersebut. Terdapatnya hal yang demikian ini membuat dokter merasa tidak melakukan profesinya sesuai dengan Kode Etik Kedokteran yang telah disetujui bersama dan sangat menjunjung tinggi nilai-nilai moral di dalamnya yang salah satunya adalah "informed consent" atau persetujuan dari keluarga maupun pasien atas segala tindakan yang berakibat penurunan daya tahan fisik pasien walaupun belum tentu menurunkan daya tahan psikisnya. Lantas bagaimana apabila eksekusi kebiri kimia tetap harus dilakukan oleh dokter, mengingat dokter adalah profesi yang dianggap sangat berkompeten untuk melakukan eksekusi kebiri kimia.

Kebiri kimia sebagai hukuman bagi pelaku kejahatan seksual di Indonesia mulai diberlakukan pada 2016. Hal ini ditandai dengan diundangkannya Undang-Undang (UU) Nomor 17 Tahun 2016 sebagai penetapan dari Perpu Nomor 1 Tahun 2016 tentang perubahan kedua atas UU Tomor 23 Tahun 2002 mengenai Perlindungan Anak. Hukuman kebiri kimia terletak pada Pasal 81 ayat (7) yang menyatakan bahawa "Terhadap pelaku sebagaimana dimaksud pada ayat (4) dan ayat (5) dapat dikenai tindakan berupa kebiri kimia dan pemasangan alat pendeteksi elektronik." Berlakunya undang-undang ini menuai pro dan kontra dari berbagai pihak, mulai dari organisasi pejuang penegakkan hak asasi manusia (HAM) hingga organisasi profesi kedokteran. Hukuman kebiri dinilai sebagai sebuah jawaban atas tingginya tuntutan publik terhadap pelaku kejahatan seksual di samping tidak optimalnya pemberlakuan hukum perlindungan anak selama ini di Indonesia. Faktanya bahwa dokter akan dijadikan satu-satunya 
profesi sebagai eksekutor kebiri kimia adalah hal utopis. Hingga kini amanat Undang-Undang No. 17 Tahun 2016 Pasal 82A ayat (3) yang berbunyi “Ketentuan lebih lanjut mengenai tata cara pelaksanaan tindakan diatur dengan Peraturan Pemerintah" belum terpenuhi. Sehingga, hal ini menjadi kendala pelaksanaan hukuman kebiri kimia di Indonesia.

Hukuman kebiri kimia yang dijatuhkan Hakim Pengadilan Negeri Mojokerto kepada pelaku pemerkosaan anak, Aris, belum bisa dieksekusi karena belum adanya petunjuk teknis, sementara Ikatan Dokter Indonesia menyebut praktek itu melanggar sumpah dokter. Kejaksaan Agung mengatakan menjalan komunikasi dan koordinasi dengan IDI untuk memutuskan siapa pelaksananya dan seperti apa mekanismenya. Kasi Intel Kejaksaan Negeri (Kejari) Kabupaten Mojokerto, Nugroho Wisnu, mengatakan belum ada petunjuk teknis dari Kejaksaan Agung meski kebiri kimia telah dilegalkan dalam Undang-Undang Nomor 17 Tahun 2016 sebagai penetapan dari Perpu Nomor 1 Tahun 2016 tentang perubahan kedua atas UU Tomor 23 Tahun 2002 mengenai Perlindungan Anak. $^{21}$

Indonesia bukanlah negara pertama di Asia yang menerapkan hukuman kebiri kimia, pada 2011 Korea Selatan mengadopsi kebiri kimia sebagai hukuman tambahan bagi kejahatan seksual. Di Korea Selatan, Pemerintah menggunakan metode kebiri kimia hanya jika para ahli kesehatan memberi hasil pemeriksaan bahwa pelaku kejahatan seksual cenderung akan mengulangi perbuatannya. Prosedur kebiri kimia akan dilakukan setelah ada diagnosis dari psikiater, baru pihak kejaksaan akan melakukan proses kebiri. Tak hanya Korea Selatan, namun juga ada beberapa negara lainnya yang menerapkan kebiri kimia sebagai hukuman yakni Denmark, Swedia, Finlandia, Norwegia, Polandia, Amerika Serikat, Argentina, Australia, Israel, Selandia Baru, Maldova, Estonia, dan Rusia. ${ }^{22}$

Rusia merupakan salah satu negara yang juga memberlakukan hukuman kebiri kimia. Prosedur pelaksanaan kebiri kimia dilakukan setelah pengadilan

21 "Hukuman Kebiri Kimia Pertama Untuk Pemerkosa Anak Belum Bisa Diterapkan Tanpa Petunjuk Teknis”, https://www.tempo.co/bbc/4587/hukuman-kebiri-kimia-pertama-untuk-pemerkosa-anak-belum-bisaditerapkan-tanpa-petunjuk-teknis, diakses tanggal 20 April 2020.

22 Aditia Arief Firmanto, "Kedudukan Pidana Kebiri dalam Sistem Pemidanaan di Indonesia (Pasca Dikeluarkannya Perppu No. 1 Tahun 2016)”, Jurnal Hukum Novelty, Vol. 8, No. 1, Februari 2017, hlm. 13. 
meminta laporan psikiater forensik untuk menindaklanjuti langkah medis terhadap si pelaku. Kemudian pengadilan akan menyuntikkan zat depoprovera yang berisi progesteron sintetis ke dalam tubuh si pesakitan. Dengan menyuntikkan lebih banyak hormon wanita ke tubuh pria maka ini akan menurunkan hasrat seksual. Setelah menjalani kebiri kimia, pelaku kejahatan pedofilia akan menjalani hukuman kurungan. Mereka baru bisa mengajukan bebas bersyarat setelah menjalani 80 persen masa hukuman. Hukuman kebiri yang berlaku di Rusia wajib dilakukan oleh setiap pelaku yang dinyatakan bersalah oleh pengadilan. ${ }^{23}$

Korea Selatan dan Rusia meminta bantuan psikiater dalam melakukan diagnosa kepada seseorang yang akan dikenai hukuman kebiri kimia. Setelah mendapatkan diagnosa, Korea Selatan menunjuk pihak kejaksaan untuk melakukan eksekusi kebiri kimia. Sedangkan Rusia, setelah mendapatkan laporan dari psikiater forensik, untuk menindaklanjuti hukuman kebiri kimia diserahkan pada pengadilan, sehingga pihak pengadilan yang akan menjadi eksekutor kebiri kimia. ${ }^{24}$

Psikiater merupakan dokter spesialis kejiwaan yang memiliki keterampilan klinis dalam mendiagnosis, melakukan pengobatan, perawatan dan pencegahan pada masalah kesehatan mental. Dalam hal ini maka dapat disimpulkan bahwa Rusia dan Korea Selatan hanya menggunakan tenaga medis atau dokter sebagai pemberi saran (advisory opinion) bagi para penegak hukum untuk melakukan eksekusi kebiri kimia. Sehingga tetap yang melakukan eksekusi atau eksekutor kebiri kimia adalah aparat penegak hukum. ${ }^{25}$

Peran dokter, terutama ahli anestesi sangat dibutuhkan untuk memberikan saran prosedur yang lebih halus dengan dosis dan metode administrasi obat yang tepat serta mampu membuat keputusan medis yang lebih tepat pada kondisi genting, agar mengurangi rasa sakit yang harus dialami narapidana. Dokter yang ikut melaksanakan hukuman pidana tidak dapat secara begitu saja dicap "tidak bermoral". Tujuan dari keikutsertaan tenaga medis bukanlah untuk mengakhiri

\footnotetext{
${ }^{23}$ Nuzul Qur'aini Mardiya, ..., Op. Cit., hlm. 220.

${ }^{24}$ Supriyadi Widodo Eddyono, Ahmad Sofian, Anugerah Rizki Akbari, Menguji Euforia Kebiri: Catatan Kritis atas Rencana Kebijakan Kebiri (Chemical Castration) Bagi Pelaku Kejahatan Seksual Anak di Indonesia, Institute for Criminal Justice Reform, Jakarta, 2016, hlm. 4.

${ }^{25}$ Ibid
} 
hidup orang lain atau menimbulkan cacat permanen, tetapi mengurangi penderitaan atau komplikasi dari suatu keputusan hukum yang memang harus dilaksanakan. ${ }^{26}$

Seorang spesialis bedah dalam melakukan tugasnya juga mencederai pasien, tetapi itu bukan merupakan tujuan dari tindakannya. Tujuan sebenarnya adalah untuk menyembuhkan penyakit pasien. Dengan demikian, tidak seharusnya tindakan seorang dokter dinilai "tidak bermoral" tanpa melihat tujuan akhir dari tindakannya tersebut. Walaupun peran dokter tidak menimbulkan dilema yang besar pada eksekusi hukuman mati di Indonesia, hukuman lainnya yang menyebabkan kecacatan fungsi masih menjadi suatu perdebatan. ${ }^{27}$

Apabila eksekusi dilakukan dengan pemberian obat-obatan tertentu, maka dokter adalah yang paling memahami mekanisme kerja obat sekaligus dampak klinis dan efek sampingnya terhadap manusia. ${ }^{28}$ Jika profesi dokter dilibatkan dalam proses eksekusi hukuman yang membuat terpidana cacat sementara, maka dokter merupakan profesi yang paling memahami untuk menghindarkan cacat sementara tersebut menjadi permanen dan mengantisipasi efek samping dari tindakan kedokteran yang membuat cacat tersebut. Dengan demikian, keterlibatan dokter yang memberikan tindakan profesional pro justitia ini mempunyai dasar argumen etis yang kuat, dalam hal dokter bertindak atas nama keadilan tanpa harus mencederai sumpah hipokrates dan Kode Etik Kedokteran. ${ }^{29}$

\section{Jaminan Kepastian Hukum Dokter Selaku Eksekutor Kebiri Kimia dan Jaminan Hak Asasi Manusia Pelaku Pedofilia}

Persoalan hukuman kebiri kimia, tidak hanya terdapat pada dokter selaku profesi yang digaungkan akan menjadi eksekutor, namun lebih luas lagi bahwa dampak kebiri kimia dapat menimbulkan hal-hal yang merugikan bagi narapidana kejahatan pedofilia. Lantas timbul pertanyaan, sejauh mana hukum di Indonesia dapat melindungi kepastian hukum tenaga medis yang nantinya akan

\footnotetext{
26 Eka Martiana Wulansari, “Kompleksitas Hukum Pidana Kebiri”, http://www.gresnews.com/ berita/opini/106444-kompleksitas-hukum-pidana-kebiri/, diakses tanggal 6 Mei 2020.

${ }_{27}$ Zulhasmar, "Implikasi Hukum Penolakan Tindakan Medis". Lex Jurnalica, Vol. 5, No. 2, April 2008, hlm 99.

${ }^{28}$ Lihat Uswatun Hasanah dan Santoso Tri Raharjo, "Penanganan Kekerasan Anak Berbasis Masyarakat", Social Work Journal, Vol. 6, No. 1, Juli 2016, hlm. 81.

${ }^{29}$ Soetedjo, Julitasari Soendoro, Pukovisa Prawiroharjo ..., Loc. Cit.
} 
diikutsertakan dalam proses eksekusi kebiri kimia dan bagaimana hukum dapat menjamin Hak Asasi Manusia (HAM) pelaku kejahatan pedofilia. Dalam fase inilah hukum diharapkan dapat bekerja sebagai penyelaras sehingga terwujudnya ketertiban.

Hukum mempunyai tujuan pokok yang hendak dicapai antara lain adalah menciptakan tatanan masyarakat yang tertib, menciptakan ketertiban dan keseimbangan. Dengan begitu, diharapkan kepentingan manusia akan terlindungi. Dalam literatur dikenal beberapa teori tentang tujuan hukum yaitu teori etis, teori utilistis, dan teori campuran. Menurut teori etis hukum sematamata bertujuan keadilan. Isi hukum ditentukan oleh keyakinan kita yang etis tentang yang adil dan tidak. ${ }^{30}$ Menurut teori utilitas, pada hakekatnya tujuan hukum adalah manfaat dalam menghasilkan kesenangan atau kebahagiaannya yang terbesar bagi jumlah orang yang terbanyak. ${ }^{31}$ Menurut Bentham, prinsip utilitarianisme ini harus diterapkan secara kuantitatif. Karena kualitas kesenangan selalu sama, maka satu-satunya aspek yang bisa berbeda adalah kuantitasnya. Dengan demikian, bukan hanya the greatest number yang dapat diperhitungkan, akan tetapi the greatest happiness juga dapat diperhitungkan. Untuk itu, Bentham mengembangkan Kalkulus Kepuasan (the hedonic calculus). ${ }^{32}$

Menurut Soebekti, hukum adalah ilmu mengabdi kepada tujuan negara, yaitu mendatangkan kemakmuran, kebahagiaan para rakyatnya. Sehingga dapat dikatakan tujuan pokok dan pertama dari hukum adalah kepastian hukum. Kepastian hukum mengandung dua pengertian, yaitu pertama adanya aturan yang bersifat umum membuat individu mengetahui perbuatan apa yang boleh atau tidak boleh dilakukan; dan kedua, berupa keamanan hukum bagi individu dari kesewenangan pemerintah. ${ }^{33}$

Kepastian hukum bukan hanya berupa pasal-pasal dalam undang-undang, melainkan juga adanya konsistensi dalam putusan hakim antara putusan hakim

\footnotetext{
hlm. 160.

30 Sudikno Mertokusumo, Mengenal Hukum Suatu Pengantar. Cetakan Kelima, Liberty, Yogyakarta, 2003,

31 Arief Budiono, "Teori Utilitarianisme dan Perlindungan Hukum Lahan Pertanian dari alih fungsi", Jurnal Jurisprudence, Vol. 9, No. 1, Juni 2019, hlm. 106.

32 K. Bertens, Pengantar Etika Bisnis, Cetakan Sepuluh, Kanisius, Yogyakarta, 2009, hlm. 193.

${ }^{33}$ Husnan Wadi, "Perselisihan Keadilan, Kemanfaatan, dan Kepastian Hukum dalam Privatisasi Sumber Daya Air”, Jurnal Ius Kajian Hukum dan Keadilan, Vol. II, No. 5, Agustus 2014, hlm. 231.
} 
yang satu dan putusan hakim lainnya untuk kasus serupa yang telah diputuskan. Berkaitan dengan dasar pertimbangan pembuatan Perpu No. 1 Tahun 2016 dan pemberatan sanksi pidana terhadap pelaku. Pertama, dasar pertimbangan pembuatan Perpu No. 1 Tahun 2016, hal ini dirumuskan dalam klasul konsideran "Menimbang" yang pada intinya terdapat 3 hal penting yaitu: ${ }^{34}$

1. Negara ingin menjamin hak anak atas kelangsungan hidup, tumbuh, dan berkembang serta memberikan perlindungan dari kekerasan dan diskriminasi (sebagaimana tercantum dalam Undang-Undang Dasar Negara Republik Indonesia Tahun 1945).

2. Meningkatnya kekerasan seksual terhadap anak semakin meningkat, hal ini mengancam dan membahayakan jiwa anak, merusak kehidupan pribadi dan tumbuh kembang anak, serta mengganggu rasa kenyamanan, ketentraman, keamanan, dan ketertiban masyarakat.

3. Sanksi pidana yang dijatuhkan bagi pelaku kekerasan seksual terhadap anak belum memberikan efek jera dan belum mampu mencegah secara komprehensif terjadinya kekerasan seksual terhadap anak, sehingga perlu segera mengubah Undang-Undang Nomor 23 Tahun 2002 tentang Perlindungan Anak sebagaimana telah diubah dengan Undang-Undang Nomor 35 Tahun 2014 tentang Perubahan atas Undang-Undang Nomor 23 Tahun 2002 tentang Perlindungan Anak.

Pertimbangan yang diberikan sebagai latar belakang pembuatan Perpu No. 1 Tahun 2016 terdiri dari pertimbangan filosofis, sosiologis dan yuridis. Perimbangan filosofis terlihat dari tujuan pemerintah membuat aturan tersebut ialah semata-mata hanya untuk menjamin perlindungan anak yang diyakini sebagai peneerus bangsa dalam tumbuh kembangnya agar tidak mengalami diskriminasi ataupun kekerasan. Pertimbangan sosiologis, melihat bahwa aturan ini sangat diperlukan karena melihat fakta atau kenyataan yang terjadi bahwa kekerasan kepada anak semakin meningkat, oleh dengan adanya hal tersebut kenyamanan, keamananan, serta ketertiban anak terganggu.

Pertimbangan yuridis terdapat dalam UUD NRI 1945 Pasal 28B ayat (2) yang mengatur bahwa setiap anak berhak atas kelangsungan hidup, tumbuh dan berkembang serta berhak atas perlindungan diri dari kekerasan dan diskriminasi. Sebagai salah satu pasal dalam konstitusi, pasal hak anak tersebut

\footnotetext{
34 Antonio Cesar Muthe, "Relevansi Sanksi Kebiri Kimia Dalam Perpu No. 1 Tahun 2016 tentang Perubahan Kedua Atas Undang-Undang Nomor 23 Tahun 2002 tentang Perlindungan Anak Terhadap Tujuan Pemidanaan," Justitia Et Pax Jurnal Hukum, Vol. 32, 2016, hlm. 109.
} 
dikelompokkan kepada hak asasi manusia, yang merupakan salah satu implementasi dari konsep negara hukum. Penerapan sanksi pidana dalam peraturan perundang-undangan sebelumnya dinilai kurang efektif karena tidak memberikan efek jera pada pelaku kekerasan seksual terhadap anak, sehingga benar adanya diperlukan aturan yang dinilai mampu mengurangi tindak kekerasan seksual terhadap anak agar terwujud kenyamanan, ketentraman, dan ketertiban bagi anak. 35

Pasal 28B ayat (2) UUD NRI 1945 menyatakan bahwa keberadaan anak sangat krusial bagi bangsa, oleh karenanya pemerintah mengkategorikan kondisi anak yang merasa tidak aman dan nyaman dikarenakan maraknya kejahatan seksual adalah "kegentingan yang memaksa." Kegentingan yang memaksa tidak seharusnya berhenti pada Perpu No. 1 Tahun 2016 yang ditetapkan melalui Undang-Undang No. 17 Tahun 2016. Dalam Undang-Undang No. 17 Tahun 2016 Pasal 82A ayat (3) memberikan amanat bahwa "Ketentuan lebih lanjut mengenai tata cara pelaksanaan tindakan diatur dengan Peraturan Pemerintah." Namun, amanah ini tidak dihiraukan oleh pemerintah. Hal ini terbukti dengan belum adanya peraturan mengenai petunjuk teknis kebiri kimia, sehingga tujuan hukum berupa kepastian telah terkesampingkan.

Pengaturan tentang kebiri kimia yang tercantum dalam Undang-Undang Nomor 17 Tahun 2016 tentang Penetapan Peraturan Pemerintah Pengganti Undang-Undang Nomor 1 Tahun 2016 tentang Perubahan Kedua Atas UndangUndang Nomor 23 Tahun 2002 tentang Perlindungan Anak Menjadi UndangUndang terdapat pada Pasal 81 ayat (7) dan Pasal 81A ayat (3) yang berbunyi sebagai berikut: "Terhadap pelaku sebagaimana dimaksud pada ayat (4) dan ayat (5) dapat dikenai tindakan berupa kebiri kimia dan pemasangan alat pendeteksi elektronik." Dan Pasal 81A ayat (3) yang berbunyi sebagai berikut: "Pelaksanaan kebiri kimia disertai dengan rehabilitasi."

Hukuman kebiri kimia dan pemasangan alat pendeteksi elektronik dijatuhkan kepada setiap orang yang melakukan kekerasan atau ancaman kekerasan memaksa anak melakukan persetubuhan dengannya atau dengan

35 Adam Yuriswanto dan Ahmad Mahyani, "Hukuman Kebiri sebagai Pidana Tambahan dalam Tindak Pidana Kejahatan Seksual”, DiH: Jurnal Ilmu Hukum, Vol. 14, No. 27, Februari 2018, hlm. 33. 
orang lain dan pelaksanaan hukuman kebiri kimia harus disertai dengan rehabilitasi. Hakikatnya latar belakang pencantuman hukuman atau sanksi berupa kebiri kimia dan pemasangan alat elektronik ialah karena perubahan Undang-Undang Nomor 23 Tahun 2002 tentang Perlindungan Anak telah diubah melalui Undang-Undang Nomor 35 Tahun 2014 tentang Perubahan atas UndangUndang Nomor 23 Tahun 2002 tentang Perlindungan anak dinilai belum mampu menurunkan tingkat kekerasan seksual terhadap anak secara signifikan. Dengan adanya hal tersebut, negara perlu mengambil langkah-langkah yang optimal dan komprehensif dengan tidak hanya memberikan pemberatan sanksi pidana, juga menerapkan bentuk pencegahan (preventif) dengan memberikan tindakan berupa kebiri kimia, pemasangan alat pendeteksi elektronik, dan rehabilitasi bagi pelaku kekerasan seksual terhadap anak.

Undang-Undang Nomor 17 Tahun 2016 tentang Penetapan Peraturan Pemerintah Pengganti Undang-Undang Nomor 1 Tahun 2016 tentang Perubahan Kedua Atas Undang-Undang Nomor 23 Tahun 2002 tentang Perlindungan Anak Menjadi Undang-Undang dirasa tidak memperhatikan hal-hal umum yang perlu diketahui dalam rangka penyusunan peraturan perundang-undangan. Hal-hal umum tersebut sebagai berikut. ${ }^{36}$ a. Naskah Akademik; b. Penyebarluasan; c. Sumber Informasi; d. Penggunaan Bahasa

Undang-Undang Nomor 17 Tahun 2016 tentang Penetapan Peraturan Pemerintah Pengganti Undang-Undang Nomor 1 Tahun 2016 tentang Perubahan Kedua Atas Undang-undang Nomor 23 Tahun 2002 tentang Perlindungan Anak Menjadi Undang-Undang, dalam hal ini tidak memperhatikan hal-hal umum terutama pada penggunaan bahasa dalam rangka penyusunan peraturan perundang-undangan. Dikatakan seperti itu karena Nomor 17 Tahun 2016 tentang Penetapan Peraturan Pemerintah Pengganti Undang-Undang Nomor 1 Tahun 2016 tentang Perubahan Kedua Atas Undang-Undang Nomor 23 Tahun 2002 tentang Perlindungan Anak Menjadi Undang-Undang tidak mencantumkan mekanisme bagaimana pelaksanaan kebiri kimia, pemasangan alat elektronik dan rehabilitasi terhadap pelaku dan juga tidak memberikan informasi yang jelas

36 Apa Yang Perlu Diketahui Untuk Membuat Peraturan Perundang-Undangan?”, https://setkab.go.id/ apa-yang-perlu-diketahui-untuk-membuat-peraturan-perundang-undangan/, diakses 12 September 2019. 
bahwa hal tersebut akan diatur melalui peraturan perundang-undangan lainnya. Dengan ini maka dapat dikatakan bahwa Nomor 17 Tahun 2016 tentang Penetapan Peraturan Pemerintah Pengganti Undang-Undang Nomor 1 Tahun 2016 tentang Perubahan Kedua Atas Undang-Undang Nomor 23 Tahun 2002 tentang Perlindungan Anak Menjadi Undang-Undang tidak sesuai dengan tujuan hukum, khususnya kepastian hukum.

Masyarakat tentu merasa tidak memahami mekanisme pelaksanaan kebiri kimia, pemasangan alat elektronik dan rehabilitasi apabila tidak ada petunjuk teknis yang dituangkan dalam aturan perundang-undangan. Tidak hanya masyarakat, namun juga bagi pelaku dan aparatur yang akan melakukan eksekusi terhadap kebiri kimia. Oleh karena hal itu, petunjuk teknis pelaksanaan kebiri kimia, pemasangan alat elektronik dan rehabilitasi harus segera dibuat untuk menindak lanjuti Nomor 17 Tahun 2016 tentang Penetapan Peraturan Pemerintah Pengganti Undang-Undang Nomor 1 Tahun 2016 tentang Perubahan Kedua Atas Undang-Undang Nomor 23 Tahun 2002 tentang Perlindungan Anak Menjadi Undang-Undang yang dibuat melalui peraturan perundang-undangan agar masyarakat, korban, pelaku, dan aparat yang akan diberi kewenangan sebagai eksekutor kebiri kimia mendapat kepastian hukum dan diharapkan juga mampu menjamin hak asasi manusia.

\section{Penutup}

Pengaturan tentang eksekutor terhadap pelaku tindak pidana seksual pada anak belum mempunyai kepastian hukum. Seorang yang melakukan tindakan terhadap kebiri kimia tersebut bukan orang yang hanya sekadar melakukannya saja, namun orang yang mempunyai ilmu dalam bidang tentang kebiri kimia. Ilmu tersebut berkaitan dengan ilmu kedokteran yang seharusnya dapat melakukan tindakan kebiri kimia. Tindakan kebiri kimia yang seharusnya dilakukan oleh seorang dokter berbenturan dengan kode etik profesi dokter. Ilmu yang tidak memiliki spesifikasi tersebut tidak dapat dilakukan secara sembarangan, karena harus dengan prosedur yang ada.

Urgensi hadirnya petunjuk teknis terkait eksekutor hukuman kebiri kimia pada pelaku tindak pidana pedofilia tidak hanya demi melindungi tenaga medis 
yang direncanakan sebagai eksekutor, namun juga menjamin adanya perlindungan Hak Asasi Manusia pelaku tindak pidana pedofilia. Maka dari itu, sanksi dengan dilakukannya kebiri kimia pada seorang pelaku tindak pidana seksual pada anak harus diatur secara jelas mengenai pelaksanaan sanksi kebiri kimia agar tidak berbenturan dengan aturan yang lain. Karena seorang pelaku tindak pidana seksual pada anak juga memiliki hak untuk mengetahui secara jelas sanksi yang dikenakan padanya. Dengan menggunakan ilmu psikologi, dapat mempengaruhi seorang pelaku untuk dapat membantu menghilangkan pikiran tentang hasrat seksual. Dalam hal ini pemerintah juga turut untuk melakukan sosialisasi terhadap perlindungan anak agar tidak menjadi korban dalam kasus pelecehan seksual. Sehingga diharapkan ius constituendum kedepannya dapat mencakup petunjuk teknis penerapan hukuman kimia dengan menjamin kepastian hukum eksekutor kebiri kimia dan mentaati etika profesi eksekutor yang bersangkutan, serta menjamin Hak Asasi Manusia pelaku tindak pidana pedofilia dengan tidak melupakan hak-hak anak sesuai undang-undang perlindungan anak.

\section{Daftar Pustaka}

\section{Buku}

Bertens, K, Pengantar Etika Bisnis, Cetakan Sepuluh, Kanisius, Yogyakarta, 2009.

Eddyono, Supriyadi Widodo, Ahmad Sofian, Anugerah Rizki Akbari, Menguji Euforia Kebiri: Catatan Kritis atas Rencana Kebijakan Kebiri (Chemical Castration) Bagi Pelaku Kejahatan Seksual Anak di Indonesia, Institute for Criminal Justice Reform, Jakarta, 2016.

Mertokusumo, Sudikno, Mengenal Hukum Suatu Pengantar, Cetakan Kelima, Liberty, Yogyakarta, 2003.

\section{Jurnal}

Budiono, Arief, "Teori Utilitarianisme dan Perlindungan Hukum Lahan Pertanian dari alih fungsi", Jurnal Jurisprudence, Vol. 9, No. 1, Juni 2019.

Firmanto, Aditia Arief, "Kedudukan Pidana Kebiri dalam Sistem Pemidanaan di Indonesia (Pasca Dikeluarkannya Perppu No. 1 Tahun 2016)", Jurnal Hukum Novelty, Vol. 8, No. 1, Februari 2017.

Hasanah, Uswatun dan Santoso Tri Raharjo, "Penanganan Kekerasan Anak Berbasis Masyarakat", Social Work Journal, Vol. 6, No. 1, Juli 2016. 
Ilyas, Sufyan, "Sanksi Kebiri Kimiawi bagi Pelaku Pedofilia dalam Perspektif Hukum di Indonesia", Al-Mursalah, Vol. 1, No. 2, Juli 2015.

Indriati, Etty, “Child Sexuual Abuse (Pencabulan Terhadap Anak): Tinjauan Klinis dan Psikologis", Berkala Ilmu Kedokteran, Vol. 33, 2001.

Mardiya, Nuzul Qur'aini, "Penerapan Hukum Kebiri Kimia Bagi Pelaku Kekerasan Seksual Implementation of Chemical Castration Punishment For Sexual Offender," Jurnal Konstitusi, Vol. 14, 2017.

Mispiyanti, "Peranan Etika Profesi dalam Perilaku Akuntan”, Jurnal Fokus Bisnis, Vol. 15, No. 1, Juli 2016.

Muthe, Antonio Cesar, "Relevansi Sanksi Kebiri Kimia Dalam Perpu No. 1 Tahun 2016 tentang Perubahan Kedua Atas Undang-Undang Nomor 23 Tahun 2002 tentang Perlindungan Anak Terhadap Tujuan Pemidanaan," Justitia Et Pax Jurnal Hukum, Vol. 32, 2016.

Noviana, Ivo, "Kekerasan Seksual Terhadap Anak: Dampak dan Penanganannya", Sosio Informa, Vol. 1, 2015.

Probosiwi, Ratih dan Daud Bahransyaf, "Pedofilia dan Kekerasan Seksual: Masalah dan Perlindungan Terhadap Anak", Sosio Informa, Vol. 1, 2015.

Rahmi, Atikah, "Urgensi Perlindungan bagi Korban Kekerasan Seksual dalam Sistem Peradilan Pidana Terpadu Berkeadilan Gender", Mercatoria, Vol. 11, No. 1, Juni 2018.

Sayudi, Akbar, "Upaya Perlindungan Korban Tindak Pidana Perkosaan dalam Sistem Peradilan Pidana Indonesia", Jurnal Fiat Justisia, Vol. 10, No. 2, April 2016.

Soetedjo, Julitasari Sundoro, Ali Sulaiman, “Tinjauan Etika Kedokteran Indonesia", Jurnal Etika Kedokteran Indonesia, Vol. 2, 2018.

Soetedjo, Julitasari Soendoro, Pukovisa Prawiroharjo, “Tinjauan Etika: Dokter sebagai Eksekutor Hukum Pidana yang Menyebabkan Kematian, Kecacatan, atau Gangguan Kesehatan", Jurnal Etika Kedokteran Indonesia, Vol. 1, 2017.

Sukirman dan Susyalina Pratiwi, "Penyuluhan tentang Hukum Perlindungan Anak", Jurnal Inovasi dan Kewirausahaan, Vol. 3, No. 2, Mei 2014.

Sumanto, Atet, "Tindakan Kebiri Kimia Bagi Pelaku Tindak Pidana Persetubuhan Dengan Menggunakan Kekerasan Terhadap Anak Di Indonesia," Perspektif , Vol. 22, 2017.

Utami, Penny Naluria, "Pencegahan Kekerasan terhadap Anak dalam Perspektif Hak Atas Rasa Aman di Nusa Tenggara Barat", Jurnal HAM, Vol. 9, No. 1, Juli 2018.

Wadi, Husnan, "Perselisihan Keadilan, Kemanfaatan, dan Kepastian Hukum dalam Privatisasi Sumber Daya Air", Jurnal Ius Kajian Hukum dan Keadilan, Vol. II, No. 5, Agustus 2014. 
Yuriswanto, Adam dan Ahmad Mahyani, "Hukuman Kebiri sebagai Pidana Tambahan dalam Tindak Pidana Kejahatan Seksual", DiH: Jurnal Ilmu Hukum, Vol. 14, No. 27, Februari 2018.

Zahara, Elvi, "Perlindungan Hukum terhadap Anak yang Melakukan Perkawinan Anak di Bawah Umur", Mercatoria, Vol. 1, No. 2, Desember 2008.

Zulhasmar, "Implikasi Hukum Penolakan Tindakan Medis". Lex Jurnalica, Vol. 5, No. 2, April 2008.

\section{Hasil Penelitian}

Komnas Perempuan, Korban Bersuara, Data Berbicara, Sahkan RUU Penghapusan Kekerasan Seksual Sebagai Wujud Komitmen Negara, Hasil Penelitian, Komisi Perempuan, Jakarta, 2019.

\section{Internet}

Alfons, Matius, "LPSK Kasus Kekerasan Seksual pada Anak Meningkat tiap Tahun", https://news.detik.com/berita/d-4637744/lpsk-kasuskekerasan-seksual-pada-anak-meningkat-tiap-tahun, diakses pada 22 April 2020.

BBC, "Hukuman Kebiri Kimia Pertama Untuk Pemerkosa Anak Belum Bisa Diterapkan Tanpa Petunjuk Teknis", https://www.tempo.co/bbc/ 4587/hukuman-kebiri-kimia-pertama-untuk-pemerkosa-anak-belumbisa-diterapkan-tanpa-petunjuk-teknis, diakses tanggal 20 April 2020.

Hafizh, M. Naufal, "Alasan IDI Tolak Jadi Eksekutor Kebiri Kimia Tersangka Kejahatan Sesual", https://www.ayobandung.com/read/2019/08/27/ 61771/alasan-idi-tolak-jadi-eksekutor-kebiri-kimia-tersangka-kejahatanseksual, diakses tanggal 20 April 2020.

Humas, "Apa Yang Perlu Diketahui Untuk Membuat Peraturan PerundangUndangan?", https://setkab.go.id/apa-yang-perlu-diketahui-untukmembuat-peraturan-perundang-undangan/, diakses 12 September 2019.

Rasi, Fathor, Ikatan Dokter Tolak Hukuman Kebiri Kimia, https://www.jatimpos.id/kabar/ikatan-dokter-tolak-hukuman-kebirikimia-b1Xlj9bUr, diakses pada 20 April 2020

Wulansari, Eka Martiana, "Kompleksitas Hukum Pidana Kebiri", http://www.gresnews.com/berita/opini/106444-kompleksitas-hukumpidana-kebiri/, diakses tanggal 6 Mei 2020.

\section{Peraturan Perundang-Undangan}

Undang-Undang Dasar Negara Republik Indonesia Tahun 1945.

Undang-Undang Republik Indonesia Nomor 35 Tahun 2014 tentang Perubahan atas Undang-Undang Nomor 23 Tahun 2002 tentang Perlindungan Anak, Lembaran Negara Republik Indonesia 2014, Tambahan Lembaran Negara RI Nomor 5606. 
Undang-Undang Republik Indonesia Nomor 31 Tahun 2014 tentang Perubahan Atas Undang-Undang Nomor 13 Tahun 2006 tentang Perlindungan Saksi Dan Korban, Lembaran Negara Republik Indonesia 2014, Tambahan Lembaran Negara RI Nomor 5602.

Undang Undang Republik Indonesia Nomor 17 Tahun 2016 tentang Penetapan Peraturan Pemerintah Pengganti Undang-Undang Nomor 1 Tahun 2016 tentang Perubahan Kedua atas Undang-Undang Nomor 23 Tahun 2002 tentang Perlindungan Anak menjadi Undang-Undang.

\section{Putusan Pengadilan}

Putusan Pengadilan Negeri Mojokerto Nomor 69/Pid.Sus/2019/PN. Mjk tentang Pidana Pemerkosaan Anak, 25 Agustus 2018. 